\title{
PENERAPAN HYGIENE SANITASI MAKANAN MINUMAN DI LEMBAGA PEMASYARAKATAN ANAK
}

\author{
Suci Nurul Khaerani, Munawar Raharja, Rahmawati \\ Jl.H.M.Cokrokusumo No.1A Kota Banjarbaru \\ Email : m_raharja@yahoo.com
}

\begin{abstract}
Application of hygiene and sanitation of food and drink in Lembaga Pemasyarakatan Anak (LAPAS). Lembaga Pemasyarakatan is have purpose to provide guidance to prisoner in Indonesia. The average population density Lapas the over capacity in Indonesia. Based on recent data form Kantor Wilayah Kementrian Hukum dan Hak Asasi Manusia, the number of population in LAPAS class II A Martapura was ranked third highestof the 13 LAPAS in Kalimantan Selatan with the number of population of about 921 people. With many of population, application of hygiene and sanitation of food an drink need to be implement for the implementation of food safety. The purpose of this research was to determine how the application of the hygiene and sanitation of food and drink in LAPAS class II A Martapura. The study was conducted by observing how security measures against food, equipment, food handlers, and food holder then comparing them with standard. The results showed thet the application of the hygiene and sanitation of food and drink in the category overall enough. For variable security measures on the equipment and food handlers in the category less, variable security measures on the food holder in the category enough, and variable security measures on the food in the category good. To the optimize application of hygiene and sanitation of food and drink in Lapas, efforts to do is add sanitation facilities food holder modify the open space, ordered food ingredients should not use the car open and do not slam, washed equipment performed with the correct phases and use soap, and stroge equipment stored in a safe place to minimize contamination of biological, physical, chemical.
\end{abstract}

Keywords : Application Higiene and sanitation of food and drink

\begin{abstract}
Abstrak: penerapan hygiene sanitasi makanan dan minuman di lembaga pemasyarakatan anak (LAPAS). Lembaga Pemasyarakatan bertujuan untuk melakukan pembinanan terhadap anak didik (narapidana) di Indonesia. Rata-rata kepadatan hunian lapas di Indonesia melebihi kapasitas, berdasarkan data terakhir dari Kantor Wilayah Kementrian Hukum dan Hak Asasi Manusia jumlah penghuni di LAPAS Kelas II A Martapura menduduki peringkat ke tiga terbanyak dari 13 lapas yang ada di Kalimantan Selatan dengan jumlah penghuni sekitar 921 orang. Dengan banyaknya hunian tersebut penerapan hygiene sanitasi makan dan minuman perlu dilaksanakan terselenggaranya keamanan pangan dilapas. Penelitian ini bertujuan untuk mengetahui bagaimana penerapan hygiene sanitasi makan dan minuman di LAPAS Kelas II A Martapura. Penelitian ini dilakukan dengan cara mengobservasi bagaimana tindakan pengamanan terhadap makanan, peralatan, penjamah dan tempat kemudian dibandingkan dengan standar. Hasil pengamatan menunjukan bahwa penerapan hygiene sanitasi makan dan minuman keseluruhan masuk dalam kategori Cukup. Untuk variabel tindakan pengamanan terhadap peralatan dan penjamah kategori Kurang, tindakan pengamanan terhadap tempat Cukup dan tindakan pengamanan terhadap makanan baik. Untuk mengoptimalkan penerapan higiene dan sanitasi makanan di Lapas Upaya yang dapat dilakukan yaitu menambah fasilitas sanitasi, memodifikasi tempat pengolahan yang terbuka, bahan makanan yang dipesan sebaiknya tidak menggunakan mobil terbuka dan tidak dibanting, pencucian peralatan dilakukan dengan tahapan yang benar dan memakai sabun, dan penyimpanan peralatan ditempat yang aman untuk menghindari atau meminimalisir kontaminasi dari faktor biologis, fisik dan kimia.
\end{abstract}

Kata kunci : Penerapan higiene dan sanitasi makanan 


\section{PENDAHULUAN}

Lembaga Pemasyarakatan (LP atau LAPAS) adalah tempat untuk melakukan pembinaan terhadap narapidana dan anak didik pemasyarakatan di Indonesia. Sebelum dikenal istilah lapas, tempat ini lebih dikenal dengan istilah penjara. Lembaga Pemasyarakatan merupakan unit pelaksana teknis di bawah Direktorat Jenderal Pemasyarakatan Kementerian Hukum dan Hak Asasi Manusia (dahulu Departemen Kehakiman). Penghuni Lembaga Pemasyarakatan bisa disebut narapidana (napi) atau warga binaan Pemasyarakatan (WBP) dan statusnya masih tahanan, maksudnya orang tersebut masih berada dalam proses peradilan dan belum ditentukan bersalah atau tidak oleh hakim (1).

Di Kalimantan Selatan terdapat 13 lembaga pemasyarakatan dibawah Direktorat Jenderal Pemasyarakatan Kementerian Hukum dan Hak Asasi Manusia. Rata-rata hunian dari semua lapas menurut mantan Wakil Menteri Hukum dan HAM Denny Indriyana, telah melebihi kapasitas dari jumlah maksimal hunian di lapas. Penghuni lapas di seluruh Indonesia diperkirakan sekitar 157.684 orang berdasarkan data pada April 2013. Padahal kapasitas hunian hanya dapat menampung 104.864 orang. Jika di persentasikan over kapasitas mencapai 150,37 persen (2).

Berdasarkan data terakhir dari Kantor Wilayah Kementrian Hukum dan Hak Asasi Manusia jumlah penghuni di Lembaga Pemasyaraktan Anak Kelas II A Martapura menduduki peringkat ke tiga terbanyak setelah Lembaga Pamasyarakatan Kelas II Banjarmasin dan Lembaga Pemasyarakatan Kelas II B Kotabaru di Kalimantan Selatan pertanggal 17 April 2015. Jumlah penghuni sekitar 921 orang, padahal hanya dapat menampung sekitar 210 orang. Jumlah penghuni tersebut merupakan gabungan dari narapidana anak-anak, wanita dan lakilaki (3).

Melihat kondisi dan banyaknya penghuni di lembaga pemasyarakatan tidak menutup kemungkinan bahwa kebutuhan jasmani dan rohani bagi narapidana tidak terpenuhi. Seperti yang diatur dalam undang-undang Nomor 12 tahun 1995 tentang hak dan kewajiban narapidana. Salah satu hak dari narapidana yaitu, melakukan ibadah, mendapat perawatan, pendidikan, layanan kesehatan serta mendapat makanan yang layak. Hak-hak ini sudah di ataur agar narapidana dapat menjalankan hukuman mereka (4).

Berdasarkan data dari majalah Warta Pemasyarakatan di Rumah Tahanan Pondok Bambu tahun 2008, kasus kesehatan yang paling banyak diderita narapidana setelah penyakit kulit adalah penyakit pencernaan. Sekitar 2.273 narapidana menderita penyakit pencernaan. Dan penyakit pencernaan menduduki posisi ke tiga setelah HIV dan TBC, sebagai penyakit yang dapat menyebabkan kematian penghuni di lapas (5).

Di Lapas Nusa Kambangan keracunan makanan pernah terjadi. Penyebab keracunan makanan tersebut berasal dari ikan yang kurang baik dalam proses pengolahannya. Penderita keracunan mengalami gejala seperti diare dan mual. Tidak hanya menyebabkan keracunan saja, makanan juga dapat menyebabkan kesakitan yang lain, khususnya penyakit di bagian pencernaan (6).

Berdasarkan hasil penelitian oleh Angraini, kondisi penjamah makanan termasuk kriteria kurang (45,3\%) yaitu kesehatan diri seperti tidak memiliki sertifikat Higiene Sanitasi Makanan, tidak memakai APD (celemek, topi, sarung tangan) saat mengolah makanan, kebersihan individu seperti tidak berpakaian bersih dan rapi, dan perilaku sehat seperti saat bersin atau batuk tidak menutup mulut dengan sapu tangan. Hal demikian merupakan bukti bahwa penerapan hygiene sanitasi yang kurang baik akan menimbulkan risiko kesakitan atau keracunan akibat makanan.

Pengolahan makanan yang dilakukan untuk orang banyak biasanya lebih berisiko, karena jumlah makanan yang diolah lebih banyak serta lamanya waktu yang dibutuhkan. Selain makanan, tempat peralatan dan orang pun dapat menjadi faktor pendukung atau penyebab kesakitan, sehingga semua faktor harus dikendalikan agar memperkecil harapan atau kesempatan terjadinya kesakitan baik yang 
disebabkan oleh faktor biologis, fisik maupun kimia.

Tujuan penelitian ini adalah mengetahui penerapan hygiene sanitasi makanan minuman meliputi tindakan terhadap pengamanan makanan dan minuman, peralatan makan, tempat pengolahan makanan dan penjamah makanan yang mengelola di bagian dapur Lembaga Pemasyarakatan anak kelas IIA Martapura.

\section{BAHAN DAN CARA PENELITIAN}

Desain penelitian adalah observasional dengan menggunakan studi cross sectional. Penelitian dilakukan di Lembaga Pemasyaraktan Anak Kelas II A Martapura, Kalsel. Populasi dalam penelitiaan ini adalah semua kegiatan penanganan makanan. Sampel dalam penilitian ini adalah kegiatan penanganan makanan yang disajikan untuk makan siang dengan pertimbangan waktu dan kemudahannya,juga dilakukan pengambilan sampel makanan jadi, sampel usap peralatan makan untuk penyajian makanan dan sampel air bersih dengan para meter $\mathrm{pH}$, sisa chlor dan MPN coliform

Pengumnulan data diperoleh melalui wawancara kepada penjamah yang ada dalam proses penanganan makanan, dilakukan pengamatan langsung pada objek penelitian menggunakan panduan observasi dan pemeriksaan sampel di laboratorium. Data yang telah terkumpul kemudian diolah secara manual, dianalisis secara deskriptif dan dibandingkan dengan teori-teori yang berhubungan dengan penelitian.

\section{HASIL DAN PEMBAHASAN}

Lembaga Pemasyarakatan Anak Kelas II A Martapura dihuni oleh warga binaan dewasa baik pria maupun wanita, dengan jumlah penghuni keseluruhan pada saat penelitian yaitu 928 orang, dimana hunian ini sudah melebihi kapasitas dari yang seharusnya.

Dengan jumlah hunian yang begitu banyak, pemenuhan kebutuhan pokok seperti makanan di lembaga pemasyarakatan anak kelas IIA Martapura dilakukan tidak secara khusus bekerja sama dengan pihak kedua atau ketiga, melainkan dilakukan oleh warga binaan itu sendiri.

Bahan makanan untuk peroses pengolahan makanan didapat dari luar, dimana pihak Lembaga Pemasyarakatan bekerja sama dengan pendistributor atau orang yang menyediakan jasa penyedian bahan makanan. Dan bahan yang pesan sesuai dengan menu dasar yang sudah dibuat oleh pihak lembaga pemasyarakatan.

a. Tindakan pengamanan terhadap makanan

Bahan makanan yang dibutuhkan dalam pengolahan makanan didapat dari pasar yang didistribusikan langsung dengan menggunakan jasa pendistributor.

Pihak lapas mempercayakan pengadaan bahan oleh pihak penyedia jasa pengadaan makanan. Hal ini sudah cukup baik, hanya saja penyedia bahan makanan atau pendistibutor kurang memperhatikan hal-hal kecil yang dapat menjadi sarana kontaminasi terhadap bahan makanan yang dibawa seperti mobil yang digunakan dalam keadaan terbuka.

Mobil pengangkut yang digunakan adalah mobil pick up bak terbuka tidak khusus sehingga bisa saja penyedia juga bisa menggunakan mobil tersebut untuk kebutuhan lain seperti mengangkut barang atau material bangunan. Hal ini bisa saja terjadi, apabila mobil tidak di bersihkan lalu langsung digunakan untuk pengangkutan bahan makanan, mobil yang digunakan dalam keadaan kotor sehingga bisa mengkontaminasi terhadap makanan.

Saat pengangkutan dan penurunan bahan makanan dari mobil yang di banting itu bisa membuat bahan makanan kondisi fisiknya rusak atau cacat sehingga bahan makanan yang kondisinya rusak tidak dapat diolah.

Berdasarkan Peraturan Menteri Kesehatan Republik Indonesia Nomor 1096/MENKES/PER/VI/2011 Tentang Higiene Sanitasi Jasaboga pengankutan bahan makanan sebaiknya tidak bercampur dengan bahan berbahaya dan beracun, menggunakan kendaraan pengankutan khusus bahan makanan yang higieneis, bahan makanan yang diangkut tidak boleh diinjak, dibanting dan diduduki, dan untuk 
bahan makanan seperti daging, susu cair harus di angkut dalam keadaan dingin. Pengankutan bahan yang sesuai dan higienes dapat berperan untuk mencegah atau meminimalisir cemaran pada saat pengangkutan bahan.

Pada tempat penyimpanan bahan makanan sudah terhindar dan aman dari binatang pengganggu dan tertutup, walaupun ada sebagian tempat penyimpanan yang terbuka yang disimpan adalah sayur-sayuran atau bahan yang tidak mudah rusak. Sedangkan untuk bahan makanan yang mudah rusak disimpan dilemari yang tertutup. Tempat penyimpanan yang digunakan kemungkinan masih bisa terkontaminasi bahan B3 karena masih terdapat ronggarongga kecil yang dapat menjadi tempat masuknya.

Bahan yang disimpan juga tidak memperhatikannya suhu penyimpanan dan disimpan tidak pada tempat yang khusus sesuai dengan jenis makanannya, misalnya saat menyimpan tempe dengan suhu ruangan dikarenakan bahan yang disimpan untuk beberapa jam saja dan tidak untuk beberapa hari karena setiap bahan makanan yang datang pagi akan habis pada malam hari. Hal yang demikian bisa saja menimbulkan tumbuhnya jamur atau kapang bahkan mikroba lain yang dapat membawa kesakitan atau keracunan makanan bagi yang mengkonsumsinya. Pada dasarnya proses penyimpanan bahan makanan bertujuan agar bahan makanan yang disimpan tidak mudah rusak dan kehilangan nilai gizinya apabila bahan itu diolah (7).

Pada dasarnya proses penyimpanan bahan makanan menurut Peraturan Menteri Kesehatan Republik Indonesia Nomor 1096/MENKES/PER/VI/2011 Tentang Higiene Sanitasi Jasaboga seharusnya memperhatikan tempat penyimpanan, wadah penyimpanan, prinsif penyimpanan, dan suhu.

Proses pemasakan bahan makanan yang lebih dahulu diolah adalah memasak nasi kemudian dilanjutkan memasak lauk pauk. Nasi yang sudah matang di bagikan kesemua omprengan, kemudian omprengan tersebut di susun bertingkat dan dibiarkan terbuka sambil menunggu lauk pauk masak. Hal yang demikian ini dapat menimbulkan kontaminasi dari kuman di udara dan kuman peralatan kemakanan karena kondisi yang terbuka dan tumpang tindih. Selain kontaminasi yang berasal dari mikrobiologi, juga dapat terjadi kontaminasi dari fisik maupun binatang pengganggu, karena kondisi omprengan yang terbuka. Sehingga dapat menimbulkan kejadian kesakitan atau keracunan akibat makanan.

Keamanan pangan adalah kondisi dan upaya yang diperlukan untuk mencegah pangan dari kemungkinan cemaran biologis, kimia, dan benda lain yang dapat mengganggu, merugikan, dan membahayakan kesehatan manusia (8). Dalam hal peroses pememasakan makanan perlu diperhatikan prioritas pemasakan dan lama waktu saat memasak agar makanan yang sudah masak tidak terlalu lama kontak atau dibiarkan di suhu ruangan dalam keadaan terbuka.

Dalam prioritas memasak ada beberapa hal terpenting yang perlu diperhatikan sesuai dengan Peraturan Menteri Kesehatan Republik Indonesia Nomor 1096/MENKES/PER/VI/2011 Tentang Higiene Sanitasi Jasaboga salah satunya adalah mendahulukan memasak makanan yang tahan lama seperti goringgorengan yang kering serta makanan rawan seperti makanan berkuah dimasak paling akhir.

b. Tindakan Pengamanan Terhadap

Peralatan

Dari hasil observasi tindakan pengaman terhadap peralatan masuk dalam kategori Kurang, hal ini juga dipertegas oleh hasil pemeriksaan bakteriologis pada peralatan makan yang digunakan oleh napi tidak memenuhi standar. Ini dikarenakan kondisi peralatan makan yang digunakan (omprengan) ada sebagian yang kondisinya pecah dibagian atas. Kondisi tersebut akibat saat menutup omprengannya kurang kuat dan apabila makanan yang ada didalamnya kondisinya encer makanan tersebut akan keluar melalui sela-sela yang pecah tersebut. dan bahan yang dari luar pun akan mudah masuk ke makanan yang didalam omprengan. 
Pada saat pencucian peralatan masak dilakukan di dapur pengolahan makanan tetapi para penjamah tidak menggunakan rak pencucian untuk mencuci peralatan makan dan bahan makanan dengan alasan lebih mudah dan leluasa. Tempat yang digunakan untuk pencucian tersebut berada disamping dapur dan dasarnya adalah lapisan semen saja serta dekat dengan saluran pembuangan atau got, sehingga apabila dilakukan pencucian bahan makan atau peralatan masak disitu kemungkinan bahan makan yang di cuci bisa kotor kembali dan bahan makanan atau peralatan juga bisa jatuh ke got. Hal tersebut berpeluang terjaadinya kontaminasi terhadap bahan makanan dan peralatan.

Pada tahapan pencucian peralatan masak tidak dilakukan perendaman dan disinfeksi, sedangkan untuk omprengan atau peralatan makan yang digunakan untuk napi mereka mencuci sendiri di blok selnya masing-masing. Hal seperti itu membuat omprengan yang digunakan ada yang bersih dan ada yang masih kotor serta berlemak hal tersebut dikarenakan perilaku dari individu yang dalam melakukan pencucian masing-masing berbeda serta sarana pencucian yang ada didalam blok sel yang kurang memadai. Hal ini dapat menimbulkan kontaminasi silang antara peralatan yang sudah bersih dan myang kurang bersih pencuciannya.

Peralatan makan disimpan ditempat yang terbuka dengan cara tumpang tindih. Disimpan di tempat terbuka seperti itu kurang baik, karena bisa saja ada binatang pengganggu yang mengkontaminasi terhadap peralatan yang sudah dicuci tersebut mengingat tempat pengolahan yang kondisinya juga terbuka atau cemaran fisik, kimia dan biologis lainnya yang dapat membawa kontaminasi dan berakibat kesakitan atau keracunan. Penyimpanan dengan cara tumpang tindih seperti itu bisa menimbulkan kotaminasi silang pada peralatan yang lainnya maksudnya pada saat pencucian peralatan makan yang dilakukan masing-massing napi membuat peralatan tersebut ada yang bersih dan ada yang masih kotor dan berlemak sehingga bila peralatan tersebut di tumpang tidak menutup kemungkinan peralatan yang di tumpanginya akan mengkontaminasi keperalatan yang lainnya dan penyimpanan yang seperti ini membuat peralatan tidak kering optimal, peralatan yang berada dibawah tidak akan kering dan peralatan yang di atas saj yang kering.

Hasil pemeriksaan laboratorium pada peralatan yang digunakan tidak memenuhi persyaratan kualitas bakteriologi seperti pada Tabel 1 .

Tabel 1. Hasil Pemeriksaan Bakteriologis pada Peralatan Makan

\begin{tabular}{|c|c|c|c|}
\hline $\begin{array}{l}\text { Peralata } \\
\text { n Makan }\end{array}$ & TPC & $\begin{array}{c}\text { Eschericia } \\
\text { coli }\end{array}$ & Ket \\
\hline 1 & $\begin{array}{c}272 \\
\text { koloni/ } \\
\mathrm{cm}^{2}\end{array}$ & Negatif & TMS \\
\hline 2 & $\begin{array}{c}3.106,7 \\
\text { koloni/ } \\
\mathrm{cm}^{2}\end{array}$ & Negatif & TMS \\
\hline 3 & 43.200 & Negatif & TMS \\
\hline Standar & $\begin{array}{c}0 \\
\text { koloni }\end{array}$ & Negatif & \\
\hline
\end{tabular}

Dari pemeriksaan angka kuman pada peralatan makan yang digunakan napi hasilnya tidak memenuhi persyaratan yang seharusnya. Hal ini jelas dapat disimpulkan karena proses pencucian, yang kurang baik, penyimpanannya yang dibiarkan terbuka dan tumpang tindih serta kondisi omprengan tersebut yang kurang baik. Hal lain yang juga meperngaruhi angka kuman yang di peralatan makan yaitu sumber air pencucian peralatan yang digunakan.

c. Tindakan Pengamanan Terhadap pengaman terhadap Penjamah makanan masuk dalam kategori Kurang. Dimana dalam hal ini ada beberapa item yang tidak sesuai persyaratan seperti dalam proses pengolahan makanan yang ditangani oleh narapidana wanita dan mereka tidak mempunyai sertifikat kesehatan dan sertifikat khusus hygiene sanitasi makanan walau pun mereka pernah diberikan materi atau pelatihan tentang jasa boga pada saat peresmian dapur, tetapi mereka masih belum memiliki sertifikat kesehatan dan kurang memahami tentang hygiene sanitasi makan dan minuman. Apabila ada yang mengetahui tentang hygiene sanitasi 
makanan dan setiap penjamah memiliki sertifikat kesehatan maka keamanan pangan akan terlaksana di lapas dan dapat mencegah atau meminimalisasi kemungkinan kesakitan atau keracunan yang disebabkan dari makanan.

Perilaku penjamah masih ada yang menyimpang saat mengolah makan seperti berbicara, merokok, rambutnya digerai, memakai perhiasan, menggaruk dan kontak langsung dengan makanan. Hal ini dapat menimbulkan atau membawa kuman yang ada di anggota tubuh kemakanan. Misalkan saja apabila dalam menangani makan penjamah berbicara atau mengobrol kemungkinan air liurnya akan masuk kemakanan dan mengkontaminasi, apabila penjamah yang menangani makana memiliki riwayat kesehatan pernah menderita TBC maka kemungkinan air liur yang mengkontaminasi kemakanan tersebut membawa bibit penyakit tersebut. Sehingga sangat penting penjamah dilakukan pemeriksaan kesehatan rutin dan memiliki sertifikat kesehatan.

Perilaku penjamah mencuci tangan sebelum dan sesudah bekerja dan dari toilet sudah baik, tetapi hanya mencucinya dengan air saja. Hanya sebagian yang mencucinya dengan sabun. Sehingga kuman yang ada di tangan dapat mengkontaminasi ke makanan dan ke penjamah itu sendiri yang dapat menyebabkan kesakitan seperti mual atau diare.

Alat pelindung diri sebenarnya sudah disediakan seperti apron, akan tetapi penjamah kurang menganggap penting dan tidak memakainya dengan alasan penjamah merasa panas bila menggunakannya. Hal tersebut meyebabkan apron tidak terurus lagi dan kadang hilang sehingga jumlahnya kurang, padaha alat pelindung diri ini penting agar meminimalisir kontaminasi kuman yang ada pada pada penjamah ke makanan yang diolahnya.

\section{d. Tindakan Pengamanan Terhadap Tempat}

Berdasarkan hasi observasi tindakan pengaman terhadap Tempat pengolahan makanan masuk dalam kategori Cukup, hal ini karena ada beberapa item penilaian yang masih tidak sesuai seperti bangunan yang terbuka dan tidak aman dari binatang pengganggu. Kondisi pintu dan dinding, yang terbuat dari jeruji besi dan tidak mempunyai pelindung seperti kasa, tidak hanya itu, kondisi langit-langit pun terbuka membuat binatang seperti kucing atau tikus mudah masuk kedalam tempat pengolahan dan dapat merusak dan membawa bibi penyakit kemakanan seperti typus. Berdasarkan Peraturan Menteri Kesehatan Republik Indonesia Nomor 1096/MENKES/PER/VI/2011 tentang Higiene Sanitasi Jasaboga dimana Tempat pengolahan makanan atau dapur harus memenuhi persyaratan teknis hygiene sanitasi untuk mencegah resiko pencemaran terhadap makanan dan dapat mencegah masuknya lalat, kecoa, tikus dan hewan lainnya

Selain itu, kondisi yang tidak memiliki plafon ini akan menimbulkan hawa didalamnya menjadi panas ketika siang karena atap yang berbahan seng. Hal ini terbukti dari hasil pengukuran suhu dan kelembapan tempat pengolahan yang tidak memenuhi persyaratan. Hal ini dapat menggangu ketidak nyaman bagi penjamah yang menangani makanan. Penjamah akan berkeringat saat melakuakn pengolahan makanan dan keringat tersebut bisa menetes tanpa sengaja ke bahan makan yang diolah dan akibatnya mengkontaminasi makanan.

Untuk pertemuan dinding dan lantai tidak berbentuk lengkung atau konus hal ini berakibat sulit membersihkan kotoran yang berada pada sela-sela dinding dan lantai tersebut akibatnya masih ada kotoran yang terdapa di sela-sela tersebut.

Saat pengolahan makanan, kondisi tempat pengolahan makanan kotor dan basah karena aktifitas dari penjamah saat mengolah makanan. Hal demikian dapat menganggu kegiatan pengolahan makanan misalnya saja penjamah tergelincir. Kondisi yang kotor ini pun dikarenakan kurangnya jumlah tempat sampah yang ada di tempat pengolahan makanan sehingga membuat penjamah saat memilah bahan makanan atau saat membersihkan sayur dan bahan makanan yang lainnya sampahnya dikumpulkan dan bergeletakan di lantai tidak langsung dibuang ketempat sampah karena letakknya tidak terjangkau dan 
jumlahnya yang kurang. Keadaan ruangan yang kotor seperti ini dapat mengurangi nilai estetika dan kehigienisan makanan, walaupun sebenarnya setiap selesai kegiatan pengolahan makanan, penjamah selalu membersihkannya.

Sampah yang dihasilkan tidak ada dilakukan pemilahan antara sampah basah dan kering serta bak sampah yang disediakan pun hanya satu sehingga semua jenis sampah dibuang tanpa pengelompokan dengan frekuensi pembuanagnnya setiap hari. Tidak dilakukannya pemisahan sampah seperti ini kurang baik karena memperlambat dekomposisi atau penguraian terhadap sampah organic karena tercampur dengan sampah anorganik.

Kurangnya fasilitas sanitasi seperti tidak tersedianya tempat cuci tangan yang khusus dan lengkap, serta tidak adanya jamban yang mudah dijangkau oleh penjamah karena letak dari jamban itu sendiri berada didalam sel mereka masingmasing. Sarana cuci tangan ini penting sebab untuk memutus atau sebagai sarana untuk meminimalisir kontaminasi yang mungkin penjamah tularkan melalui tangan penjamah.

Air bersih yang digunakan sumbernya ada dua yaitu air sumur dan irigasi tetapi untuk sumber air irigasi digunakan hanya pada saat yang terdesak. Kualitas fisik dan kimia air $(\mathrm{pH})$ memenuhi persyaratan akan tetapi berdasarkan hasil pemeriksaan MPN Coli pada air bersih yang digunakan hasilnya pada pengulangan kedua tidak memenuhi standar yaitu 20 MPN Coli, dan pada pengulangan pertama dan ketiga 10 MPN Coli. Hal seperti ini berarti pada air yang digunakan teridentifikasi bakteri kelompok Coliform dan apabila Air yang tercemar digunakan untuk kegiatan pengolahan makanan kemungkinan dapat mengkotaminasi pada peralatan makan dan makanan. Meskipun belum pasti akan menyebabkan kesakitan karena bakteri Coliform ini tidak semuanya pathogen (bakteri penyebab kesakitan) tetapi kemungkinannya akan selau ada.

\section{KESIMPULAN DAN SARAN}

Penerapan Higiene Sanitasi Makanan dan Minuman di Lembaga Pemasyarakatan
Anak Kelas II A Martapura Tahun 2015 termasuk dalam penilaian cukup.

Tindakan pengamanan terhadap makanan dan minuman di lembaga Pemasyarakatan Anaka Kelas II A Martapura termasuk dalam kategori BAIK. Beberapa item-item yang di perbaiki seperti penyediaan bahan dan penyimpanan bahan, penanganan makanan masak.

Tindakan pengamanan terhadap peralatan di Lembaga Pemasyarakatan Anak Kelas II A Martapura termasuk dalam kategori KURANG, baik kondisi fisik peralatan makan maupun upaya pemeliharaan kebersihan peralatan. Hasil pemeriksaan kualitas bakteriologis peralatan pada omprengan memenuhi standar untuk parameter bakteri Eschericia coli tetapi, untuk angka kuman peralatan tidak memenuhi standar dan hasil pemeriksaan

Tindakan pengamanan terhadap penjamah di Lembaga Pemasyarakatan Anak Kelas II A Martapura termasuk dalam kategori KURANG, dilihat dari pengetahuan, personal hygiene dan perilaku penjamah.

Tindakan pengamanan terhadap tempat di Lembaga Pemasyarakatan Anak Kelas II A Martapura termasuk dalam kategori CUKUP, item yang tidak terpenuhi seperti kontruksi bangunan yang terbuka, kurangnya sarana sanitasi dan bak sampah. Saat pemeriksaan MPN coli pada air bersih yang digunakan untuk pencucian peralatan dan makanan tidak memenuhi persyaratan pada pengambilan ke dua yaitu 20 MPN coliform/ $100 \mathrm{ml}$.

Saran yang dapat diberikan agar Petugas Lemabaga Pemasyarakatan Anak Kelas II A Martapura merencanakan pelatihan oleh tenaga sanitarian tentang hygiene sanitasi makanan dan minuman kepada narapidana berkerja sama dengan Dinas Kesehatan Kabupaten Banjar. Penambahan jumlah bak sampah yang tertutup dan kedap air dan sebaikknya bak sampah dipisahkan antara sampah organik dan non organik. Disetiap blok sel narapidana disediakan tempat pencucian dan sabun untuk mencuci peralatan makan yang digunakan para narapidana. Bangunan dapur yang terbuka menggunakan jeruji besi seperti pintu dan dinding atas sebaiknya diberi kawat kasa 
agar binatang tidak masuk kedalam tempat pengolahan.

\section{KEPUSTAKAAN}

1. Wikipedia. wikipedia. [Online] 12 8, 2013.

[Cited: 02 27, 2015.]

http://id.wikipedia.org/w/index.php?ti

tle=Lembaga_Pemasyarakatan\&oldid $=7$ 418294.

2. Sumartono, Sumadiyono. Jumlah Tahanan Lapas Kelebihan 50.751 Orang. Solopos. [Online] 05 1, 2013. [Cited: 02 27, 2015.] http://www.solopos.com/2013/05/ 01/denny-indrayana-jumlahtahanan-lapas-kelebihan-50-751orang-402082.

3. Sistem Database Pemasyarakatan. Sistem Database Pemasyarakatan. [Online] 2015. [Cited: 04 17, 2015.] http://smslap.ditjenpas.go.id/public /grl/current/daily.

4. Dirkumham. Undang-Undang Nomor 12 Tahun 1995 Tentang Narapidana. UURI NO 12. [Online] 1995. www.kemenkumham.go.id.

5. Ditjenpas. WARTA PEMASYARAKATAN. [Online] DESEMBER 2008. [Cited: MARET 23, 2014.] www.ditjenpas.go.id/wartapasdigital/warta-pemasyarakatan-no35.

6. Waspada. Keracunana Makanan di Nusa Kambangan. [Online] 04 31, 2014. www.waspada.com.

7. Virdhani, Marieska Harya. Tujuh Santri di Depok Keracunan Makanan. www.okezone.com. [Online] februari 3, 2015. [Cited: februari 25, 2015.] http://news.okezone.com/read/201 5/02/03/338/1100548/tujuhsantri-di-depok-keracunanmakanan.

8. Arifin, Zainal. Pengertian Kesehatan. [Online] 10 17, 2011. [Cited: 02 27, 2015.] http://zainal-a-fkm10.web.unair.ac.id/artikel_detail -35770-KesehatanPengertian\%20Sehat.html. 